\title{
DETERMINATION OF THE EDUCATION TECHNOLOGY COMPETENCIES OF SPECIAL EDUCATION TEACHERS
}

\author{
Yunus Yilmaz ${ }^{1}$ \\ Havva Aysun Karabulut ${ }^{2}$, \\ Ahmet Serhat Uçar ${ }^{3 i}$, \\ Kadriye Uçar ${ }^{4}$ \\ ${ }^{1}$ Anadolu University, \\ Faculty of Education, \\ Turkey \\ orcid.org/0000-0001-6988-798X \\ ${ }^{2}$ Abant İzzet Baysal University, \\ Faculty of Education, \\ Turkey \\ orcid.org/0000-0001-9119-3626 \\ ${ }^{3}$ Anadolu University, \\ Faculty of Education, \\ Turkey \\ orcid.org/0000-0001-5910-8751 \\ ${ }^{4}$ Aydin Adnan Menderes University, \\ Faculty of Education, \\ Turkey \\ orcid.org/0000-0002-9522-7624
}

\begin{abstract}
:
The novel coronavirus (COVID-19) pandemic that started in December 2019 led to the closure of schools on a global level, and implementation of strict social distancing measures has led to rapid and prevalent changes in conventional forms of education and instruction. In this period where distance education is preferred in education processes, the education technology competencies of teachers have gained importance. In this context, this study aimed to determine the education technology competencies of special education teachers. The descriptive study included 114 special education teachers. The data were collected by using the "Education Technology Competencies Scale for Teachers" and analyzed by using the SPSS 25 package software. The maximum total score that could be obtained in the scale that was used in the study is 190. It was determined that, with the mean score of 155.27, the participants of this study had an education technology competency level of $81.72 \%$. In this study which investigated the technological competencies of special education teachers, no significant difference was found based on the participants' gender, professional experience or areas of teaching.
\end{abstract}

i Correspondence: email, asucar@anadolu.edu.tr 
Considering the items in the dimensions of the scale, it was found that the male teachers were more competent in terms of technical knowledge on technology, while the female teachers used the technological knowledge they had more effectively in classes, instruction and materials, as well as in communication with both students and parents.

Keywords: educational technology, educational technology standards for teachers, teacher qualifications, special education teachers

\section{Introduction}

Technology refers to useful practices that are utilized in organizing information whose accuracy has been proven in terms of reaching specified goals, meeting needs and making life easier (İşman, 2008). In this context, technology is the variable that makes out entire life easier, and it has become one of the most important elements that humanity cannot give up as it is involved in almost all areas of daily life (Vural, 2004). Developments and innovations in technology provide great advantages for the life of humanity in many fields (Tekinarslan, 2008). It is not possible for technology, which is involved in every aspect of life (music, demonstration, books, research, etc.), to not influence education experiences which are one of the most important parts of life (Safa, 2019).

Education technologies are an applied field of science that aims to effectively use tools, equipment and methods that are utilized to reach the target audience in the best way and increase productivity in education processes (Sengir, 2019). Studies on education technology have revealed that using education technologies in education enriches education processes (İşman, 2002). Nowadays, education technologies have become much more important in terms of education and instruction. The novel coronavirus (COVID-19) pandemic which started in December 2019 led to the closure of schools on a global scale, and implementation of strict social distancing measures has created rapid and prevalent changes in forms of education and instruction (Arpa, 2020). Additionally, the pandemic has revealed the importance of learning to use education technologies for teachers and the necessity for teachers to become more multidimensional in their pedagogy (Wilson, 2020).

Teacher competencies may be defined as the degree to which a teacher has the knowledge, skills and attitudes that are required for performing their profession with success (Balc1, 2005). Teacher competencies are an important issue in the field of special education, just like every other field of general education (Karabulut, Yand1, Kaya, 2019). While using education technology in the instruction process, teachers need to have the capacity to have a command over technology and competency that will increase the quality of the process while they are transferring this to students (Kaya, 2017). Today, many teachers working in the field of special education utilize several assistive technologies such as computers and the internet in their classes. Teachers include various education technology practices for the purpose of supporting the daily life skills and academic success of students who are influenced by disadvantages (Kim et al., 2003; 
Aslan, 2018). During these practices, the correct and effective use of assistive technologies is in parallel with the positive attitudes of special education teachers towards technology and their competencies in this field (K1şla, 2008). Therefore, for an active teacher, having basic competencies in the field of education technology is considered as important for the process to reach success (Safa, 2019).

In the recent literature, issues such as competencies, attitudes, knowledge and usage regarding education technologies are among the topics that are being examined by researchers. There are studies in the literature which have examined the knowledge levels, attitudes, opinions and perceptions of teachers regarding education technologies (İşman ,2002; Akpınar, 2003; Seferoğlu \& Akbıyık, 2005; Demiraslan \& Usluel, 2005; Arpa, 2010; Çoklar, 2012; Chai et al., 2010; Forssell, 2011; Sengir, 2019; Safa, 2019; Arpa, 2020). However, it was seen that studies examining the technology competencies of special education teachers in Turkey are limited (Kışla, 2008; Aslan, 2018). Considering this limitation, it is believed that determining the education technology competencies of special education teachers will contribute to the knowledge base in the literature. In addition to this, it is thought that determining the technology competencies of special education teachers will serve to improve their existing situation, and therefore, contribute to an increase in the quality of the education that they will provide. In this context, this study aimed to determine the education technology competencies of special education teachers, and answers were sought for the following questions:

1) Do the education technology competencies of special education teachers vary based on the variable of gender?

2) Do the education technology competencies of special education teachers vary based on the variable of field of teaching?

3) Do the education technology competencies of special education teachers vary based on the variable of professional experience?

\section{Material and Methods}

In this study, which was structured with a quantitative and descriptive design, the data were collected from special education teachers working at public schools. The teachers were selected with the method of maximum variation sampling within the scope of simple non-random purposive sampling. Table 1 presents the descriptive statistics of the teachers who participated in the study.

Table 1: Demographic Characteristics of the Sample $(n=114)$

\begin{tabular}{|c|c|c|}
\hline Variables & $n$ & $\%$ \\
\hline \multicolumn{3}{|l|}{ Gender } \\
\hline Female & 71 & 62.3 \\
\hline Male & 43 & 37.7 \\
\hline \multicolumn{3}{|l|}{ Field of Teaching } \\
\hline Special Education & 49 & 43 \\
\hline Mental Disability Education & 60 & 52.6 \\
\hline
\end{tabular}


COMPETENCIES OF SPECIAL EDUCATION TEACHERS

\begin{tabular}{|c|c|c|}
\hline Hearing Disability Education & 4 & 3.5 \\
\hline Visual Disability Education & 1 & 0.9 \\
\hline \multicolumn{3}{|l|}{ Years in the Profession } \\
\hline $0-5$ Years & 83 & 72.8 \\
\hline 6-10 Years & 12 & 10.5 \\
\hline 11-15 Years & 7 & 6.1 \\
\hline 16-20 Years & 12 & 10.5 \\
\hline
\end{tabular}

Among the 114 special education teachers who constituted the sample of the study, 71 $(62.3 \%)$ were female, while $43(37.7 \%)$ were male. In the distributions based on fields of teaching, or in other words, department of graduation, the highest frequencies were in the categories of "Mental Disability Education" (MDE) with 60 (52.6\%) teachers and "Special Education" (SE) with 49 (43\%) teachers. It was also determined that $72.8 \%(\mathrm{n}=83)$ of the participants had a professional experience of 0-5 years.

\subsection{Data Collection Instruments}

In order to determine the competencies of the special education teachers in using education technologies, the "Education Technology Competencies Scale for Teachers" which was developed by Bayraktar (2015) was utilized. It is a 38-item, 5-point Likert-type scale which has 4 dimensions as "Technology Literacy", "Technology Integration in Class", "Social Ethics and Legal Provisions" and "Communication". The options for each item consist of the statements "absolutely disagree, disagree, somewhat agree, agree, and absolutely agree". The minimum and maximum totals scores in the scale are 38 and 190. The Cronbach's Alpha coefficient, which shows the internal consistency of a scale, was calculated as 0.94 for this scale. Besides the scale that was utilized, a Participant Information Form was used to collect information about the participants' gender, fields of teaching and professional experience.

\subsection{Data Collection}

In the data collection process, first of all, the scale was converted to a format that was suitable for remote access and participation via the Google Forms platform. At the next stage, special education teachers working at public schools all around Turkey were reached, and the scale was shared with these teachers.

\subsection{Data Analysis}

Before the analyses planned within the scope of the objective of the study, the collected data were transferred to the computer environment, and the data were inspected in the form of examining the entries and visual checks, determination of outlier values, determination of items which were left blank and their numbers, and overview of main descriptive statistics. The analyses were carried out by using the SPSS 25 package software. 


\section{Results}

The findings of our study which was conducted to determine the education technology competencies of special education teachers are presented below. Before the results of the analysis in the context of the demographic variables of the participants, the education technology competency levels of all participants are shown in Table 2.

Table 2: Education Technology Competencies of the Participants

\begin{tabular}{|l|c|c|c|c|c|}
\hline Scale and Subscales & $\mathbf{N}$ & $\mathbf{X}$ & SD & \multicolumn{2}{|c|}{ Min.-Max. } \\
\hline Technology Literacy & 114 & 72.96 & 14.97 & 31 & 95 \\
\hline Technology Integration in Class & 114 & 39.24 & 6.29 & 19 & 45 \\
\hline Social Ethics and Legal Provisions & 114 & 27.80 & 3.52 & 9 & 30 \\
\hline Communication & 114 & 15.28 & 3.88 & 4 & 20 \\
\hline Total & 114 & 155.27 & 24.25 & 80 & 190 \\
\hline
\end{tabular}

According to the total scores and subscale scores included in Table 2, the mean score the participants obtained in the "Technology Literacy" dimension consisting of 19 items was $X=72.96$. Considering this score in the context of the maximum of 95 points that can be obtained in the dimension, it was seen that the participants scored on the level of $76.8 \%$. The mean score of the participants in the "Technology Integration in Class" dimension which consists of 9 items that was found as $X=39.24$ corresponded to a level of $87.2 \%$ considering the maximum possible score of 45 in the dimension. The participants had mean scores of 27.80 in the dimension of "Social Ethics and Legal Provisions" which consists of 6 items and 15.28 in the dimension of "Communication" which consists 4 items, whereas these scores corresponded to the competency levels of $92.67 \%$ and $76.24 \%$, respectively. The maximum possible total score in the scale is 190, and the mean score of $X=155.27$ that was obtained in our study corresponded to the competency level of $81.72 \%$.

Table 3: Comparison of Education Technology

Competencies Based on the Genders of the Participants

\begin{tabular}{|c|c|c|c|c|c|c|c|c|}
\hline \multirow{3}{*}{$\frac{\text { Scale and Subscales }}{\text { Technology Literacy }}$} & \multirow{2}{*}{$\begin{array}{l}\text { Gender } \\
\text { Female }\end{array}$} & \multirow{2}{*}{$\begin{array}{l}\mathbf{N} \\
71\end{array}$} & \multirow{2}{*}{$\begin{array}{c}\mathbf{X} \\
71.15\end{array}$} & \multirow{2}{*}{$\begin{array}{c}\text { SD } \\
13.46\end{array}$} & \multicolumn{2}{|c|}{ Min.-Max. } & \multirow{3}{*}{$\begin{array}{c}t \\
-1.664\end{array}$} & \multirow{3}{*}{$\begin{array}{c}p \\
.099\end{array}$} \\
\hline & & & & & 42 & 95 & & \\
\hline & Male & 43 & 75.93 & 16.91 & 31 & 95 & & \\
\hline \multirow{2}{*}{$\begin{array}{l}\text { Technology } \\
\text { Integration in Class }\end{array}$} & Female & 71 & 39.63 & 5.67 & 19 & 45 & \multirow{2}{*}{0.815} & \multirow{2}{*}{.418} \\
\hline & Male & 43 & 38.58 & 7.23 & 19 & 45 & & \\
\hline \multirow{2}{*}{$\begin{array}{l}\text { Social Ethics and } \\
\text { Legal Provisions }\end{array}$} & Female & 71 & 27.87 & 3.38 & 9 & 30 & \multirow{2}{*}{0.291} & \multirow{2}{*}{.772} \\
\hline & Male & 43 & 27.67 & 3.77 & 13 & 30 & & \\
\hline \multirow[t]{2}{*}{ Communication } & Female & 71 & 15.77 & 3.70 & 4 & 20 & \multirow{2}{*}{1.765} & \multirow{2}{*}{.080} \\
\hline & Male & 43 & 14.47 & 4.06 & 5 & 20 & & \\
\hline \multirow[t]{2}{*}{ Total } & Female & 71 & 154.44 & 22.53 & 80 & 190 & \multirow{2}{*}{-0.471} & \multirow{2}{*}{.639} \\
\hline & Male & 43 & 156.65 & 27.06 & 96 & 189 & & \\
\hline
\end{tabular}

The demographic characteristics on which information was collected from the participants were gender, field of teaching and professional experience (Table 1). Due to 
their cell distributions included in the subcategories regarding the variables of field of teaching and professional experience, the analyses in the context of field of teaching did not include the categories of "Hearing Disability Education" and "Visual Disability Education", whereas the analyses in the context of professional experience were carried out between those with an experience of 0-5 years and those with an experience of longer than 5 years. The results of the analyses are presented in Tables 3, 4 and 5 .

According to the results of the comparison of the education technology competencies of the participants in the context of gender, there was no significant difference between the male and female participants. Although there was no significant difference based on the analysis results, while the mean scores of the male participants were higher in terms of technology literacy $(t=-1.664 ; p>.05)$ and scale total $(t=-.471 ; p$ $>$.05), the mean scores of the female participants were higher in terms of technology integration in class $(t=.815 ; p>.05)$, social ethics and legal provisions $(t=.291 ; p>.05)$ and communication $(t=1.765 ; p>.05)$. Considering the items in the dimensions of the scale, these results may be interpreted as that the male teachers were more competent in terms of technical knowledge on technology, while the female teachers used the technological knowledge they had more effectively in classes, instruction and materials, as well as in communication with both students and parents.

According to the results of the comparison of the education technology competencies of the participants in the context of fields of teaching as shown in Table 4, there was no statistically significant difference between the fields in terms of their scores in the technology literacy $(t=.118 ; \mathrm{p}>.05)$, technology integration in class $(t=.685 ; \mathrm{p}>.05)$, social ethics and legal provisions $(t=.221 ; \mathrm{p}>.05)$ and communication $(t=1.511 ; \mathrm{p}>.05)$ dimensions and total scores $(t=.523 ; \mathrm{p}>.05)$. It was observed that the participants who had graduated from departments of SE had higher mean scores in all dimensions and the total scale. This statistically insignificant difference may be explained by the fact that the SE teachers graduated after the individual fields of special education were combined with legal regulations, and thus, they were younger, and they had higher levels of current technology knowledge and experiences.

Table 4: Comparison of Education Technology

Competencies Based on the Teaching Fields of the Participants

\begin{tabular}{|c|c|c|c|c|c|c|c|c|}
\hline Scale and Subscales & Field & $\mathbf{N}$ & $x$ & SD & \multicolumn{2}{|c|}{ Min.-Max. } & $t$ & $p$ \\
\hline \multirow[t]{2}{*}{ Technology Literacy } & MDE & 60 & 73.07 & 14.33 & 40 & 95 & \multirow{2}{*}{0.118} & \multirow{2}{*}{.907} \\
\hline & SE & 49 & 73.41 & 15.94 & 31 & 95 & & \\
\hline \multirow{2}{*}{$\begin{array}{l}\text { Technology Integration } \\
\text { in Class }\end{array}$} & $\mathrm{MDE}$ & 60 & 38.77 & 6.31 & 19 & 45 & \multirow{2}{*}{0.685} & \multirow{2}{*}{.495} \\
\hline & SE & 49 & 39.61 & 6.53 & 19 & 45 & & \\
\hline \multirow{2}{*}{$\begin{array}{l}\text { Social Ethics and Legal } \\
\text { Provisions }\end{array}$} & $\mathrm{MDE}$ & 60 & 27.83 & 3.21 & 13 & 30 & \multirow{2}{*}{0.221} & \multirow{2}{*}{.826} \\
\hline & SE & 49 & 27.98 & 3.71 & 9 & 30 & & \\
\hline \multirow[t]{2}{*}{ Communication } & MDE & 60 & 14.67 & 3.80 & 5 & 20 & \multirow{2}{*}{1.511} & \multirow{2}{*}{.134} \\
\hline & SE & 49 & 15.80 & 3.97 & 4 & 20 & & \\
\hline \multirow[t]{2}{*}{ Total } & $\mathrm{MDE}$ & 60 & 154.33 & 23.65 & 102 & 189 & \multirow{2}{*}{0.523} & \multirow{2}{*}{.602} \\
\hline & SE & 49 & 156.80 & 25.36 & 80 & 190 & & \\
\hline
\end{tabular}

Abbreviations: $\mathrm{MDE}=$ Mental Disability Education; SE = Special Education. 
The results of the analysis that was conducted in the context of professional experience, which was another variable regarding the competencies of the participants, are presented in Table 5.

Table 5: Comparison of Education Technology

Competencies Based on the Professional Experience of the Participants

\begin{tabular}{|c|c|c|c|c|c|c|c|c|}
\hline Scale and Subscales & Professional Experience & $\mathbf{N}$ & $X$ & SD & \multicolumn{2}{|c|}{ Min.-Max. } & $t$ & $p$ \\
\hline \multirow[t]{2}{*}{ Technology Literacy } & Under 5 years & 83 & 72.41 & 14.10 & 42 & 95 & \multirow{2}{*}{-0.636} & \multirow{2}{*}{.526} \\
\hline & Over 5 years & 31 & 74.42 & 17.25 & 31 & 95 & & \\
\hline \multirow{2}{*}{$\begin{array}{l}\text { Technology Integration } \\
\text { in Class }\end{array}$} & Under 5 years & 83 & 39.46 & 5.70 & 19 & 45 & \multirow{2}{*}{0.533} & \multirow{2}{*}{.597} \\
\hline & Over 5 years & 31 & 38.65 & 7.74 & 19 & 45 & & \\
\hline \multirow{2}{*}{$\begin{array}{l}\text { Social Ethics and } \\
\text { Legal Provisions }\end{array}$} & Under 5 years & 83 & 27.34 & 3.87 & 9 & 30 & \multirow{2}{*}{-3.108} & \multirow{2}{*}{$.002^{* *}$} \\
\hline & Over 5 years & 31 & 29.03 & 1.91 & 21 & 30 & & \\
\hline \multirow[t]{2}{*}{ Communication } & Under 5 years & 83 & 15.30 & 3.96 & 4 & 20 & \multirow{2}{*}{0.092} & \multirow{2}{*}{.927} \\
\hline & Over 5 years & 31 & 15.23 & 3.71 & 7 & 20 & & \\
\hline \multirow[t]{2}{*}{ Total } & Under 5 years & 83 & 154.51 & 23.01 & 80 & 189 & \multirow{2}{*}{-0.550} & \multirow{2}{*}{.583} \\
\hline & Over 5 years & 31 & 157.32 & 27.59 & 96 & 190 & & \\
\hline
\end{tabular}

${ }^{*}=p<.05 ;{ }^{* *}=p<.01 ;{ }^{* * *}=p<.001$

According to the results of the analysis conducted in terms of the professional experience levels of the participants, there was a significant difference in the social ethics and legal provisions dimension $(t=-3.108 ; \mathrm{p}<.01)$. The mean score of the participants who had an experience of longer than 5 years $(X=29.03)$ was significantly higher than the mean score of those who had an experience of shorter than 5 years $(X=27.34)$. Moreover, the mean scores of the subcategories of age were also calculated. The results were found as $0-5$ years $\left(X^{-}=27.33\right), 6-10$ years $\left(X^{-}=28.58\right), 11-15$ years $(X=29.14)$ and $16-20$ years $(X=29.42)$. In other words, as the professional experience of the participants got longer, their technology competencies in relation to social ethics and legal provisions also increased.

There was no significant difference in the mean scores of the participants in the other dimensions of the scale and the total scale based on professional experience [technology literacy $(t=.636 ; \mathrm{p}>.05)$, technology integration in class $(t=.533 ; \mathrm{p}>.05)$, communication $(t=.092 ; \mathrm{p}>.05)$ and total $(t=-.550 ; \mathrm{p}>.05)]$.

\section{Discussion}

It was observed that the special education teachers were competent in the dimensions of technology integration, social ethics and communication. It was seen that, as the professional experience of the participants increased, their technology competencies especially in relation to social ethics and legal provisions increased. A study that examined technology-related pedagogical content knowledge with the participation of teachers from different branches determined that the participants considered themselves adequate in fields such as ethics, implementation and communication (Albayrak et al., 2016). Therefore, their study and this study had similarities in terms of their subscales and the scores of their participants in these subscales. 
It was concluded that teachers did not sufficiently utilize education technologies that motivate and support learning (İşman, 2002). It was also determined that teachers experienced shortcomings in terms of technological literacy (Avc1 \& Seferoğlu, 2011). However, in contrast to the aforementioned studies, in this study, it was seen that the participants reflected technological developments on their education and instruction processes. Some studies conducted in the context of technological pedagogical skills have observed that teachers are on a good level in terms of these skills (Adigüzel \& Yüksel, 2012; Ceylan, 2015; Gürültü et al., 2018). Likewise, in this study, the technological competencies of the participants were on a good level.

A study carried out with secondary school teachers did not find a significant difference in 21st century technological skills in education environments based on gender (Gürültü et al., 2019). On the other hand, considering the items in the dimensions of the scale used in this study, the results may be interpreted as that the male teachers were more competent in terms of technical knowledge related to technology, while the female teachers could more effectively use the technological knowledge they had in classes, instruction, materials and for communication with both students and parents. In the study mentioned above, as in the case of this study, no significant difference was found in the scores of the scale the researchers used based on the variable of years of service.

In 2016, the Higher Education Council of Turkey (YÖK) made a decision to combine the programs of Mental Disability Education, Visual Disability Education, Hearing Disability Education and Gifted Education under one roof as the Special Education program. In the comparison of the mean scores of the participants based on the variable of field of teaching, it was seen that the teachers with SE degrees had higher mean scores than the others in all dimensions and the total scale. This statistically insignificant difference may be explained by the fact that the SE teachers graduated after the individual fields of special education were combined with legal regulations, and thus, they were younger, and they had higher levels of current technology knowledge and experiences. The study by Şahin and Arcagök (2014) with form teachers and branch teachers similarly found a significant difference in the dimension of digital competency in favor of the teachers who were within the first 10 years of their professional experience, or in other words, younger.

It should be ensured that teachers can become technologically literate, necessary work is carried out in this direction, sufficient effort is shown, teachers are brought to an adequate level of technology usage, and appropriate environments are created. This is because the power of technology in learning-teaching processes should not be neglected (Garba et al., 2015; Seferoğlu, 2004). With this understanding, the findings of this study showed that technology literacy displayed an improvement, and the teachers were more effective in technology usage in learning and instruction processes in comparison to previous years.

In this study, where the technological competencies of special education teachers were investigated, no statistically significant difference was found between the participants based on their genders, professional experience levels and fields of teaching. 
It was also determined that the participants had high scores in the technology literacy, technology integration in class, social ethics and legal provision and communication subscales. As a requirement of our era, the need for teachers to use technology effectively in learning and instruction processes has emerged. In addition to being competent in terms of knowledge regarding technology use, it is also important for teachers to accept these technologies and utilize their advantages (Sarıkaya, 2019). In this study, it was observed that the special education teachers generally possessed these technological competencies. Nevertheless, it should be kept in mind that the knowledge and skills of teachers regarding technologies that are used in learning and instruction processes increased with the COVID-19 pandemic. In the scale that was utilized in this study, the items inquire about technology use in in-class practices. With the pandemic period, a sharp transition was experienced towards digital classrooms, that is, online educationinstruction processes (Posos Devrani et al., 2020). Therefore, the finding obtained with this scale that the technological competency levels of the teachers were high may be interpreted as a consequence of their introduction to relatively more advanced platforms like the Education Information Network (EBA) and Zoom after the onset of the pandemic and their experience of holding classes on these platforms.

\section{Recommendations}

New studies covering current technologies used in learning and instruction processes may be conducted, and new scales to be used in such studies may be developed. Furthermore, there is a limited number of studies on the technological competencies of special education teachers. Conducting similar studies in this direction will contribute to the relevant literature.

\section{Conflict of Interest Statement}

The authors declare no conflicts of interests.

\section{About the Author}

Yunus Yılmaz graduated from Anadolu University teaching program for the hearing impaired teaching (2011). He completed his master's degree in the same branch (2016). He continues $\mathrm{PhD}$ in the education of the hearing impaired. Scientific fields of study are teacher training and inclusive education. He works as a research assistant in the special education department of Anadolu University.

Havva Aysun Karabulut completed his PhD in special education in 2020. She works as a lecturer at Bolu Abant İzzet Baysal University. Her research interests are individuals with special needs, science teaching and inclusive education.

Ahmet Serhat Uçar completed his undergraduate education in Anadolu University teaching program for the mentally handicapped (2011). He completed his master's degree in the same program (2016). PhD continues in the same program. Scientific fields of study are inclusive education, vocational education, learning disabilities and teacher training. 
He works as a research assistant in the special education department of Anadolu University.

Kadriye Uçar completed her $\mathrm{PhD}$ in Anadolu University special education department in 2020. She works as a research assistant at Aydın Adnan Menderes University. Scientific fields of study are students with special needs, mathematics education and inclusive education.

\section{References}

Adıgüzel, A. \& Yüksel, İ. (2012). Evaluation of Teachers' Instructional Technologies Integration Skills: A Qualitative Need Analysis for New Pedagogical Approaches. Necatibey Faculty of Education Electronic Journal of Science and Mathematics Education, 6(1), 265-286.

Akpinar, Y. (2003). The Effect of Higher Education on Teachers' Use of New Information Technologies: The Case of Istanbul Schools, The Turkish Online Journal of Educational Technology, 2(2), 1303-6521.

Albayrak S., A., Canbazoğlu B., S., Baran, E., \& Özbay, U. (2016). Investigating the Relationship Between Teachers' Technological Pedagogical Content Knowledge (TPACK) Competencies and Attitudes Towards Information and Communication Technologies. Educational Technology Theory and Practice, 6(1), 1-21.

Arpa, P. (2010). The influence of instructional technologies on the use and choice of teaching strategies, methods and techniques. Master's Thesis, Marmara University

Arpa, P. (2020). The school administrators and teachers' views on the educational technologies and perceptions of autonomy. PhD Thesis, Gazi University, Ankara.

Aslan, C. (2018). Attitudes of special education teachers towards assistive technology. Educational Technology Theory and Practice, 8 (1), 102-120. doi:10.17943/etku.319972

Avcı, Ü., \& Seferoğlu, S. S. (2011). Teachers' Burnout in the Information Age: Use of Technology and Possible Actions in Preventing Burnout. Mediterranean Journal of Educational Research, 9, 13-26.

Balc1, A. (2005). Research, Methods, Techniques and Principles in Social Sciences. Pegem Akademi: Ankara.

Ceylan, B. (2015). Evaluating the Effect of Learning Objects on The Technological Pedagogical Content Knowledge Competencies of The Preservice Teachers. Php Thesis, Anadolu University

Chai, C. S., Koh, J. H. L., \& Tsai, C.C. (2010). Facilitating preservice teachers' development of technological, pedagogical, and content knowledge (TPACK). Educational Technology \& Society, 13(4), 63-73.

Çoklar M. (2012). Information and Communication Technologies in General Competencies of Teaching Profession: Afyonkarahisar Sample. Master's Thesis, Necmettin Erbakan University 
Demiraslan, Y. \& Usluel, Y. K. (2005). The status of teachers in the integration of information and communication technologies into the learning and teaching process. The Turkish Online Journal of Educational Technology, 4(3), 109-113.

Forssell, K. (2011). Technological pedagogical content knowledge: Relationships to learning ecologies and social learning networks. Phd Thesis, Stanford University

Garba, S. A., Byabazaire, Y. \& Busthami, A. H. (2015). Toward the use of 21st century teaching-learning approaches: The trend of development in Malaysian schools within the context of Asia Pacific. International Journal of Emerging Technologies in Learning, 10(4), 72-29. doi:/10.3991/ijet.v10i4.4717

Gürültü, E., Aslan M. \& Alcı B. (2018). Investigation of Elementary School Teachers' Qualifications in The Light Of 21st Century Skills. The Journal of Academic Social Sciences. 6(71). Sf. 543-560. doi: 10.16992/ASOS.13770

Gürültü, E., Aslan, M., \& Alcl, B. (2019). Secondary School Teachers' Competencies in the Use of 21st Century Skills. Hacettepe University Journal of Education, 35(4), 780-798. doi: 10.16986/HUJE.2019051590

İşman, A. (2002). The competencies of Sakarya province teachers in educational technologies. The Turkish Online Journal of Educational Technology - TOJET, 1(1), 7292.

İşman, A., (2008). Instructional Technologies and Material Design. Pegem A Publishing

Karabulut, A., Yand1, A., \& Kaya, A. (2019). Determination of self-efficacy beliefs of teacher candidates studying in special education department. The Journal of Turkish Social Research. 23(2), 555-574.

Kışla, T. (2008). Investigating Computer Attitudes of Special Education Teachers. Ege Journal of Education, (9)2, 128-154.

Kim, Y. W., Kim, Y. G., Kim, N. J., \& Woo, Y. G. (2003). A study on the Korea teacher's perception in using assistive technology. Journal of Asia-Pacific Special Education, 3(1), 35-48.

Posos Devrani, A. E., Kesici, İ., \& Duman, A. (2020). Digital classes in the pandemic: An evaluation of the period March-June 2020. Istanbul: Turkish German University.

Safa, B. S. (2019). Class teachers' usage levels of educational technologies in terms of individual innovation features. Master's Thesis, Aydin Adnan Menderes University

Seferoğlu, S. S. (2004). Teacher qualifications and professional development. Education Journal in the Light of Science and Mind, 58, 40-45.

Seferoğlu, S. S. \& Akbıyık, C. (2005). A Study on Primary School Teachers' Perceived Computer Self-Efficacy. Eurasian Journal of Educational Research, 19, 89-101.

Sengir, C. (2019). The investigation of secondary school teachers' use of information technologies in terms of some variables (Istanbul Fatih district example). Master's Thesis, İstanbul Kültür University

Şahin, Ç., \& Arcagök, S. (2014). Examination of The Teachers' Lifelong Learning Competences Levels in Terms of Some Variables. Journal of Social Sciences, 7(16), 397-417. 
Tekinarslan, E. (2008). A validity and reliability study of the basic technology competencies scale for educators. Electronic Journal of Social Sciences. 7(26) 86-205.

Vural, B. (2004). Use of Technology and Materials in Education. İstanbul: Hayat Publishing.

Yüksek Öğretim Kurumu (YÖK), (2016). https://yokatlas.yok.gov.tr/lisansbolum.php?b=20903 Accessed 20 April 2021. 
Creative Commons licensing terms

Authors will retain the copyright of their published articles agreeing that a Creative Commons Attribution 4.0 International License (CC BY 4.0) terms will be applied to their work. Under the terms of this license, no permission is required from the author(s) or publisher for members of the community to copy, distribute, transmit or adapt the article content, providing a proper, prominent and unambiguous attribution to the authors in a manner that makes clear that the materials are being reused under permission of a Creative Commons License. Views, opinions and conclusions expressed in this research article are views, opinions and conclusions of the author(s). Open Access Publishing Group and European Journal of Special Education Research shall not be responsible or answerable for any loss, damage or liability caused in relation to/arising out of conflict of interests, copyright violations and inappropriate or inaccurate use of any kind content related or integrated on the research work. All the published works are meeting the Open Access Publishing requirements and can be freely accessed, shared, modified, distributed and used in educational, commercial and non-commercial purposes under a Creative Commons Attribution 4.0 International License (CC BY 4.0). 